Journal of Maternal and Child Health (2018), 3(3): 184-196

https://doi.org/10.26911/thejmch.2018.03.03.03

\title{
The Effect of Parenting Style, Bilingual School, Social Environment, on Speech and Language Development in Preschool Children in Surakarta, Central Java
}

\author{
Arum Wijayanti'), CSP Wekadigunawan'), Bhisma Murti3) \\ ${ }^{1)}$ Masters Program in Public Health, Universitas Sebelas Maret \\ 2)Faculty of Medicine, Universitas Sebelas Maret
}

\begin{abstract}
Background: Childhood speech and language development is considered an important predictor of their future achievement. This study aimed to analyze the effect of parenting style, bilingual school, social environment, on speech and language development in preschool children in Surakarta, Central Java.

Subjects and Method: This was an analytic and observational study with a cross-sectional design. The study was conducted at 25 preschools in Surakarta, Central Java, from February March 2018. A sample of 200 preschool children was selected by simple random sampling from 25 preschools selected by stratified random sampling. The dependent variable was speech and language develop-ment. The independent variables were sex, nutritional status, parental education, parenting style, family income, bilingual school, and social environment. The data of speech and language development were measured by pre-screening development questionnaire. Other variables were collected by questionnaire. The data were analyzed by a multilevel logistic regression using Stata 13.

Results: Speech and language development increased with age $(b=2.03 ; 95 \% \mathrm{CI}=0.38$ to 3.68 ; $\mathrm{p}=0.016)$, nutritional status $(\mathrm{b}=2.44 ; 95 \% \mathrm{CI}=0.38$ to $4.08 ; \mathrm{p}=0.003)$, maternal education $(\mathrm{b}=$ $1.50 ; 95 \% \mathrm{CI}=0.14$ to $2.86 ; \mathrm{p}=0.031)$, democratic parenting style $(\mathrm{b}=2.76 ; 95 \% \mathrm{CI}=1.16$ to 4.08 ; $\mathrm{p}<0.001)$, family income $(\mathrm{b}=1.69 ; 95 \% \mathrm{CI}=0.15$ to $3.23 ; \mathrm{p}=0.031)$, bilingual $\mathrm{school}(\mathrm{b}=-4.46$; $\mathrm{CI}=$ -6.53 to $-2.39 ; \mathrm{p}=0.001)$, and social environment $(\mathrm{b}=1.80 ; 95 \% \mathrm{CI}=0.10$ to $3.50 ; \mathrm{p}=0.038)$. Intraclass correlation $=28.06 \%$ indicating considerable contextual effect of preschool.

Conclusion: Speech and language development increases with age, nutritional status, maternal education, parenting style, family income, bilingual school, and social environment.
\end{abstract}

Keywords: speech and language development, parenting style, bilingual school, pre-school children

Correspondence:

Arum Wijayanti. Program Magister Kesehatan Masyarakat, Universitas Sebelas Maret. Email: arumwijayanti.rf@gmail.com

BACKGROUND
Children development is the most import-
ant thing in preparing children as the next
qualified generation. These developments
are the result of the interaction of matura-
tion of the central nervous system with the
organs affected including the development
of neuro-muscular system, speech, emotio-
nal and social development (Mardiana and
Indanah, 2016). Language and speech
development is considered as an important

indicator of children development for school or future success. Therefore, it is important to identify early signs and problems of speech and language development in children (Nayeb et al, 2014). In preschool, the growth and development of children happen very quickly. The child must be prepared for school, for that senses and receptor receptors system of stimuli and memory process must be ready so that children are able to learn well. Entering 
Wijayanti et al./ The Effect of Parenting Style, Bilingual School, Social Environment,

preschool, children begin to show their desires along with their growth and development including speech and language development (Marmi and Raharjo, 2012).

The development of speech and language is the ability in spoken language in children which develop because of the maturity of speech organs as well as other factors (Gunarsa, 2008). In pre-school years, the language development of children is very active and rapid. Many problems in the learning process occur due to language delay in the preschool period. Children who experience speech and language delay are at higher risk of learning when they are at school age. The difficulty in reading and writing will lead to less academic achievement thoroughly and may continue into adulthood. The impact of delayed development of speech and language of children include excessive crying, difficulties in understanding, speech defects, speech impediment and speech delay (Candrasari, 2014).

According to the National Center for Health Statistics (NCHS), the incidence of of speech disorders in children under 5 years is $0.9 \%$ and $1.94 \%$ is at $5-14$ years. The results of evaluations performed on school-age children showed an incidence rate of 3.8 times higher. Thus, it is estimated that speech and language disorders in children are about 4-5\% (Gunawan et al, 2011). Based on the research of Hartanto et al (2011), it was found that children aged 1-3 years experienced language delays for about 36 (50\%) of 72 total samples. In Kariadi Hospital during 2007 at the Child Growth Clinic, there was $\mathbf{2 2 . 9 \%}$ of the 436 new visits come with late speech complaints and 13 (2.98\%) of them experienced language development disorder.

Late speech is a major complaint that parents often complain about and worry about. Some reports mention the incidence of speech and language disorders in the range of $5-10 \%$ in children. Motor and cognitive abilities develop according to the children's age, as well as the acquisition of language increases through developmental processes ranging from first language, preschool age and school age where language plays a very important role in the academic achievement of children (Candrasari, 2014).

The development of speech and language in children can be influenced by several factors, such as family economic condition, social environment, bilingual presence and family social environment (Sumaryati, 2017). Family is a system where the system is formed from the parts that are interconnected and interacting with each other. For example, a mother and children's interaction are never going one way (Sari and Budisetyani, 2016). Parents become the first person in influencing the good and bad of the child's life. But unfortunately, many parents are not aware that the pattern of care they apply impact on children's development. A false parenting pattern will have an adverse effect on the children's development. There are several parenting styles of parents, including authoritarian parenting, democratic parenting and permissive parenting. Differences in parenting styles can be influenced by the age of parents, father's involvement, parental education, previous parenting experiences and others (Sutisna, 2017). Differences in parenting style resulted in differences in children's welfare and psychological development. The best way to improve the language and speech development of children is to build a climate of emotional connection between parents and children (Guyer et al, 2016).

The presence of bilingual or bilingual shows that humans can learn two languages 
at once without any difficulty. One can learn two languages from birth or learn both languages because of the environment and immigration. The level of a person's skills in applying these two languages is different. Some people can show similar abilities in both languages, but others also show certain dominance in one language. It creates its own challenges in bilingual studies (Costa and Galles, 2015). Environment is everything that comes from outside of the children and can affect the growth and development of children because in the environment also provides the needs of children to grow and develop from the womb to adulthood. The social environment can cause speech and language disorders in children, if the environment is not supportive. Conversely, if the environment is good then it will support the growth of children (Hasmy, 2014).

A similar study was conducted by Gunawan et al. (2011) entitled "Overview of Speech and Language Development of Children Aged o-3 Years". The difference from the previous study is on the type of study used. The previous study used descriptive type. While this study uses analytic observational research type that aims to explain the influence between variables through hypothesis testing.

Based on this background, the author is interested in conducting study entitled "The Effect of Parenting Style, Bilingual School, Social Environment, on Speech and Language Development in Preschool Children in Surakarta, Central Java ".

\footnotetext{
SUBJECTS AND METHOD

1. Study Design

This was an analytic observational study with a cross sectional design. The study was conducted at 25 preschools in Surakarta, Central Java, from February March 2018.
}

\section{Population and sample}

The target population in this study were all preschoolers who attended early childhood education (PAUD) with their mothers. A sample of 200 preschool children was selected by simple random sampling from 25 preschools selected by stratified random sampling.

\section{Study variables}

The dependent variable was speech and language development. The independent variables were sex, nutritional status, parental education, parenting style, family income, bilingual school, and social environment.

\section{Operational definition of variables}

Parenting style was defined as the way and attitude of parents who are applied to educate their children. The data were measured by Parenting Style Questionaire (PSQ). The measurement scale was continuous.

Bilingual was defined as the ability of a child to use one or more languages to communicate daily. The data were measured by Questionnaire Use Everyday Language. The measurement scale was dichotomous, coded monolingual if the child can only master one language for the daily communication and bilingual if the child can master two or more languages used in everyday communication.

The social environment was defined as the environment of the child to socialize at home, school, and community. The data were measured by questionnaires. The measurement scale was continuous, but for the purpose of data analysis, it was transformed into dichotomous, coded poor social environment if score $<11$ and good social environment if score $\geq 11$.

Maternal education was defined as the last formal education level ever pursued by the mother. The measurement scale was 
Wijayanti et al./ The Effect of Parenting Style, Bilingual School, Social Environment,

categorical, coded o for $<$ High school and 1 for $\geq$ High school.

Family income was defined as a condition that describes the family income (father and mother) every month earned through the work done. The data were measured by questionnaires. The measurement scale was continuous, but for the purpose of data analysis, it was transformed into dichotomous, coded $\mathrm{O}$ for $<\mathrm{Rp}$ 2,000,000 and 1 for $\geq \operatorname{Rp~2,000,000.~}$

Children nutritional status was defined as a state of children health determined by the degree of physical demand for energy and other nutrients whose physical impact was measured by anthropometrics weight for age (WAZ).

Gender was defined as the difference between women and men biologically since a person was born. The measurement scale was categorical.

Children speech and language development was defined as an aspect that relates to the ability to respond to voice, talk, communicate, and follow orders. The data were measured by measured by prescreening development questionnaire.

\section{Data Analysis}

The data analysis used in this study was multivariate analysis with multilevel analysis design with logistic regression analysis test. It was conducted using STATA 13 program to know the influence of independent variable that is located at level one (individual) to the dependent variable, and also to know influence of contextual of early childhood at the second level to the dependent variable.

\section{Research Ethics}

The research ethics included informed consent by research subjects, anonymity, confidentiality and ethical clearance. The ethical clearance in this study was conducted in Dr. Moewardi hospital, Surakarta.

\section{RESULTS}

The study subject characteristics in this study including the child's gender, maternal education, maternal occupation, children age, and maternal age. Table 1 shows that most of the children were female (123.55\%) and a small percentage of them were boys of 77 (38.5\%). Most children aged $\geq 5$ years for about 110 (55.0\%) while children $\geq 5$ years consisted of 90 (45.0\%). As many as 134 mothers (67\%) were $\geq$ Senior high school. As many as 130 mothers (65\%) worked at home. Maternal aged $\geq 30$ years were 118 (59\%).

Table 1. The Characteristics of Subjects

\begin{tabular}{|c|c|c|c|}
\hline No. & Characteristics & Frequency (n) & Percentage (\%) \\
\hline \multirow{3}{*}{1.} & Gender & & \\
\hline & Male & 77 & 38,5 \\
\hline & Female & 123 & 61,5 \\
\hline \multirow[t]{3}{*}{2.} & Maternal Education & & \\
\hline & < Senior high school & 66 & 33,0 \\
\hline & $\geq$ Senior high school & 134 & 67,0 \\
\hline \multirow[t]{3}{*}{3 . } & Maternal occupation & & \\
\hline & Working at house & 130 & 65,0 \\
\hline & Working outside of home & 70 & 35,0 \\
\hline \multirow[t]{2}{*}{5.} & Children's Age & & \\
\hline & $<5$ years old & 90 & 45,0 \\
\hline & $\begin{array}{l}\geq 5 \text { years old } \\
\text { Maternal age }\end{array}$ & 110 & 55.0 \\
\hline \multirow{2}{*}{6.} & $<30$ years old & 82 & 41,0 \\
\hline & $\geq 30$ years old & 118 & 59,0 \\
\hline
\end{tabular}


The result of statistical description of research variables were parenting style, bilingual, social environment, mother

Table 2. Univariate Analysis of Variables

\begin{tabular}{|c|c|c|c|}
\hline No. & Variable & Frequency (n) & Percentage (\%) \\
\hline \multirow[t]{3}{*}{1.} & Parenting style & & \\
\hline & Permissive and Authoritarian & 85 & 42.5 \\
\hline & Democratic & 115 & 57.5 \\
\hline \multirow[t]{3}{*}{2.} & Bilingual & & \\
\hline & Monolingual & 117 & 58.5 \\
\hline & Bilingual & 83 & 41.5 \\
\hline \multirow[t]{3}{*}{3 . } & Social Environment & & \\
\hline & Poor & 70 & 35.0 \\
\hline & Good & 130 & 65.0 \\
\hline \multirow[t]{3}{*}{4.} & Maternal education & & \\
\hline & $<$ Senior high school & 66 & 33.0 \\
\hline & $\geq$ Senior high school & 134 & 67.0 \\
\hline \multirow[t]{3}{*}{5 . } & Family Income & & \\
\hline & $<\operatorname{Rp~2,000,000~}$ & 70 & 35.0 \\
\hline & $\begin{array}{l}\geq \mathrm{Rp} 2,000,000 \\
\text { Children Nutritional Status }\end{array}$ & 130 & 65.0 \\
\hline \multirow{2}{*}{6.} & Poor & 52 & 26.0 \\
\hline & Good & 148 & 74.0 \\
\hline \multirow[t]{3}{*}{7.} & Children's Gender & & \\
\hline & Male & 77 & 38.5 \\
\hline & Female & 123 & 61.5 \\
\hline
\end{tabular}

Table 2 shows the description of each variable in the study. These variables were parenting style, bilingual, social environment, maternal education, family income, children nutritional status, and children's gender. Based on the table, most of the parents had democratic parenting style as many as 115 (57.5\%). As many as 85 mothers (42.5\%) had permissive and authoritarian parenting style.

Most children use monolingual or one language in everyday life that is for about 117 (58.5\%) meanwhile, only 83 (41.5\%) children have bilingual ability (can master two or more languages). Most children grew up in a good social environment of 130 (65\%) and those who grew up in a bad social environment were 70 (35\%).

Most of the mothers graduate $\geq$ high school for about 134 (67\%) while mothers education, family income, child nutrition status, and children's gender can be seen in the following Table 2.

\section{Frequency (n) $\quad$ Percentage (\%)}

with education $<$ SMA were 66 (33\%). Most of them have the family income $\geq \mathrm{Rp}$ 2,000,000 for about 70 (35\%) while the other small amount of income was $<\mathrm{Rp}$ 2,000,000. In this study, most children included in the category of good nutrition status for about 148 (74\%) and some others belong into the category of malnutrition for about 52 (26\%). The final variable is about the child's gender. Based on the result of research, it is found that most of the female child are $123(61.5 \%)$ and 77 (38.5\%) male children.

Table 2 showed the description of each variable in the study. The variables were parenting style, bilingual, social environment, maternal education, family income, children's nutritional status, and the gender of children. Based on the table, most of the parents in this study implemented good 
parenting style which was democratic parenting by 115 (57.5\%) while parents who apply poor parenting style (permissive and authoritarian) were 85 (42.5\%).

Table 2. The results of univariate analysis

\begin{tabular}{|c|c|c|c|}
\hline No. & Variable & Frequency (n) & Percentage (\%) \\
\hline \multirow[t]{3}{*}{1.} & Parenting Style & & \\
\hline & $\begin{array}{l}\text { Poor (Permissive and } \\
\text { Authoritarian) }\end{array}$ & 85 & 42.5 \\
\hline & Good (Democratic) & 115 & 57.5 \\
\hline \multirow[t]{3}{*}{2.} & Bilingual & & \\
\hline & Monolingual & 117 & 58.5 \\
\hline & Bilingual & 83 & 41.5 \\
\hline \multirow[t]{3}{*}{3 . } & Social Environment & & \\
\hline & Poor & 70 & 35.0 \\
\hline & Good & 130 & 65.0 \\
\hline \multirow[t]{3}{*}{4.} & Maternal Education & & \\
\hline & $<$ High School & 66 & 33,0 \\
\hline & $\geq$ High School & 134 & 67,0 \\
\hline \multirow[t]{3}{*}{5.} & Family Income & & \\
\hline & $<\mathrm{Rp} 2,000,000$ & 70 & 35,0 \\
\hline & $\begin{array}{l}\geq \mathrm{Rp} 2 \text { 2,000,000 } \\
\text { Children's Nutritional Status }\end{array}$ & 130 & 65,0 \\
\hline \multirow{2}{*}{6.} & Malnutrition & 52 & 26,0 \\
\hline & Good Nutrition & 148 & 74,0 \\
\hline \multirow[t]{3}{*}{7.} & Gender of Children & & \\
\hline & Male & 77 & 38,5 \\
\hline & Female & 123 & 61,5 \\
\hline
\end{tabular}

Most of the children used monolingual or single language in daily life which were 117 children (58.5\%) meanwhile, only 83 (41.5\%) children who have bilingual ability (mastering two or more languages). The children who grow in a good social environment were 130 children (65\%) and children who grow in poor social environment were $70(35 \%)$.

As many as 134 mothers (67\%) had education level $\geq$ high school. Family with income $\geq \operatorname{Rp} 2,000,000$ were 70 families (35\%). As many as 148 children (74\%) had good nutritional status. Most of children were female $(123,61.5 \%)$.

Table 3 showed the results of bivariate analysis by Chi-square test. Democratic parenting style increased children speech and language development than permissive or authoritarian parenting style $(\mathrm{OR}=4.64$; $95 \% \mathrm{CI}=2.44$ to $8.22 ; \mathrm{p}<0.001$ ).

There was an association between bilingual on speech and language development in children. Bilingual children were 0.03 time less likely to have speech and language development compared to monolingual children $(\mathrm{OR}=0.03 ; 95 \% \mathrm{CI}=0.01$ to $0.07 ; \mathrm{p}<0.001)$. There was an association between social environment on speech and language development in children. Children who lived in good social environments were 5.52 times more likely to develop speech and language compared to children who lived in poor social environments $(\mathrm{OR}=5.51 ; 95 \%$ $\mathrm{CI}=2.80$ to $10.85 ; \mathrm{p}<0.001$ ). 
Journal of Maternal and Child Health (2018), 3(3): 184-196

https://doi.org/10.26911/thejmch.2018.03.03.03

Table 3. The results of Chi-square test about the effect of parenting style, bilingual, social environment, maternal education, family income, children's nutritional status, and children's gender on speech and language development

\begin{tabular}{|c|c|c|c|c|c|c|c|c|c|}
\hline \multirow{3}{*}{$\begin{array}{l}\text { Independent } \\
\text { Variable }\end{array}$} & \multirow{3}{*}{ Category } & \multicolumn{4}{|c|}{$\begin{array}{c}\text { Speech and Language } \\
\text { Development }\end{array}$} & \multirow{3}{*}{ OR } & \multicolumn{2}{|c|}{$95 \%$ CI } & \multirow{3}{*}{$\mathbf{p}$} \\
\hline & & \multicolumn{2}{|c|}{ Abnormal } & \multicolumn{2}{|c|}{ Normal } & & Lower & Upper & \\
\hline & & $\mathbf{n}$ & $\%$ & $\mathbf{n}$ & $\%$ & & Limit & Limit & \\
\hline Parenting & Poor & 42 & 49.4 & 43 & 50.6 & 4.64 & 2.44 & 8.82 & $<0.001$ \\
\hline Style & Good & 20 & 17.4 & 95 & 82.6 & & & & \\
\hline Bilingual & Monolingual & 6 & 5.1 & 111 & 94.9 & 0.03 & 0,01 & 0.07 & $<0.001$ \\
\hline & Bilingual & 56 & 67.5 & 27 & 32.5 & & & & \\
\hline Social & Poor & 47 & 48.5 & 50 & 51.5 & $5 \cdot 51$ & 2.80 & 10.85 & $<0.001$ \\
\hline Environment & Good & 15 & 14.6 & 88 & 85.4 & & & & \\
\hline Maternal & $<$ High school & 38 & 57.6 & 28 & 42.4 & 6.22 & 3.22 & 12.01 & $<0.001$ \\
\hline Education & $\begin{array}{l}\geq \text { High } \\
\text { school }\end{array}$ & 24 & 17.9 & 110 & 82.1 & & & & \\
\hline Family Income & $\begin{array}{l}\text { Low } \\
\text { High }\end{array}$ & $\begin{array}{l}36 \\
26\end{array}$ & $\begin{array}{r}51.4 \\
20\end{array}$ & $\begin{array}{r}34 \\
104\end{array}$ & $\begin{array}{r}48.6 \\
80\end{array}$ & 4.23 & 2.24 & $7 \cdot 99$ & $<0.001$ \\
\hline Children & Poor & 34 & 65.4 & 18 & 34.6 & 8.09 & 4.00 & 16.38 & $<0.001$ \\
\hline $\begin{array}{l}\text { Nutritional } \\
\text { Status }\end{array}$ & Good & 28 & 18.9 & 120 & 81.1 & & & & \\
\hline Gender & $\begin{array}{l}\text { Male } \\
\text { Female }\end{array}$ & $\begin{array}{l}31 \\
31\end{array}$ & $\begin{array}{l}40.3 \\
25.2\end{array}$ & $\begin{array}{l}46 \\
96 \\
\end{array}$ & $\begin{array}{l}59.7 \\
74.8\end{array}$ & 2.00 & 1.09 & 3.68 & 0.025 \\
\hline
\end{tabular}

There was an effect between maternal education on speech and language development in children, and it was statistically significant. Mothers who were $\geq$ high school have 6.22 times greater likelihood of having children with better speech and language development than mothers who were $<$ high school $(\mathrm{OR}=6.22 ; 95 \% \mathrm{CI}=3.22$ to $12.01 ; \mathrm{p}$ $<0.001)$.

There was an effect between family income on speech and language development in children, and it was statistically significant. Children from families who have income for about $\geq \operatorname{Rp} 2,000,000$ were 4.23 times more likely to develop normal speech and language $(\mathrm{OR}=4.23 ; 95 \% \mathrm{CI}=2.24$ to 7.99; $\mathrm{p}<0.001)$.

There was an effect between children's nutritional status on speech and language development in children, and it was statistically significant. Children with good nutritional status have 8.09 times greater likelihood to have normal speech and language development than children with poor nutritional status $(\mathrm{OR}=8.09 ; 95 \% \mathrm{CI}=4.00$ to 16.38 ; $\mathrm{p}<0.001$ ).

There was an effect between children's gender on speech and language development in children, and it was statistically significant. Female children were 2.0o times more likely to develop speech and language than male children $(\mathrm{OR}=2.00 ; 95 \% \mathrm{CI}=$ 1.09 to $3.68 ; \mathrm{p}=0.025$ ).

Table 4 showed the results of logistic regression test with multilevel approach. In this table, the independent variable consisted of fixed effect and random effect. Fixed effect consisted of parenting style, bilingual, social environment, maternal education, family income, children's nutritional status, and children's gender. While the random effect was ECEP (Early Childhood Education Program). In this table, the result of ICC was 28.06\%. It was indicated that early childhood education program (ECEP) has a contextual effect on the speech and language development among preschool children. From the Table 4, the result of likelihood ratio was 0.134. It shows the difference and 
statistically significant effect between the models without looking at the effect of contextual model which in this case was ECEP. ECEP with A accreditation were more likely to improve speech and language development of preschool children compared to ECEP with $\mathrm{B}$ accreditation and ECEP with no accreditation.

Table 4. The result of multilevel logistic regression

\begin{tabular}{|c|c|c|c|c|}
\hline \multirow{2}{*}{ Independent Variable } & \multirow{2}{*}{ b } & \multicolumn{2}{|c|}{ CI (95\%) } & \multirow{2}{*}{$\mathbf{P}$} \\
\hline & & Lower Limit & Upper Limit & \\
\hline \multicolumn{5}{|l|}{ Fixed Effect } \\
\hline Parenting Style & 2.76 & 1.16 & 4.35 & 0.001 \\
\hline Bilingual & -4.46 & -6.53 & -2.39 & $<0.001$ \\
\hline Social Environment & 1.80 & 0.10 & $3 \cdot 50$ & 0.038 \\
\hline Maternal Education & 1.50 & 0.14 & 2.86 & 0.031 \\
\hline Family Income & 1.69 & 0.15 & 3.23 & 0.031 \\
\hline Children's Nutritional Status & 2.44 & 0.81 & 4.08 & 0.003 \\
\hline Children’s Gender & 2.03 & 0.38 & 3.68 & 0.013 \\
\hline \multicolumn{5}{|l|}{ Random Effect } \\
\hline \multicolumn{5}{|l|}{ ECEP } \\
\hline Var (Constant) & 1.28 & 0.10 & 15.78 & \\
\hline \multicolumn{5}{|l|}{ ICC $=\mathbf{2 8 . 0 6 \%}$} \\
\hline \multicolumn{5}{|l|}{ Likelihood Ratio Test $\mathrm{p}=$} \\
\hline 0.134 & & & & \\
\hline
\end{tabular}

\section{DISCUSSIONS}

1. The effect of parenting style on speech and language development of preschool children

The result of this study showed that there was an effect of parenting style on speech and language development of preschool children and it was statistically significant. Good parenting style (democratic) improved speech and language development of preschool children rather than poor parenting style.

The result of this study was in accordance with a study by Restiyani (2013), which stated that there was a strong relationship between parenting style and the development of speech and language in children, if the parenting was good and in accordance with the needs of children, the development of speech and language would also be good. On the contrary, if the parenting style was not good enough and not according to the needs of children, then the development of speech and language of the children would also be poor.
Democratically guided children have more possibilities for active learning than children who were raised in an undemocratic manner. The best parenting style for children was democratic parenting because it suited the stage of their development. This parenting style set clear expectations and monitor children's behavior with logical discipline, so that the child's motor, language, and social development would be better (Putri et al., 2016).

This study is consistent with a study by Bingham et al. (2017), which stated that parenting style was the most important thing for child's development. Parents who were democratic or have good parenting would have children with high score in academic achievement. This study also showed that parenting contributed directly to the academic skills as well as the language development of the children.

\section{The effect of bilingual on speech and language development of pre- school children}

The result of this study showed that there was an effect of bilingual on speech and 
Journal of Maternal and Child Health (2018), 3(3): 184-196

https://doi.org/10.26911/thejmch.2018.03.03.03

language development of preschool children and it was statistically significant. A bilingual child would decrease his/her speech and language development rather than monolingual child.

The result of this study was in accordance with a study by Mardiana and Indanah (2016), which stated that there was a significant relationship between bilingual and the development of speech and language in children. Every language certainly has a very striking difference, perhaps from the grammar and others. Parents need to introduce bilingual language wisely to the children, when the children should use the language, and when the children should switch to another language so that the children did not feel confused which could lead to disruption in their development.

This was in line with the idea of Meyer (2012), who stated that bilingual may lead to the developmental speech and language disorders in children. A bilingual child may experience errors in the use of language for communication, especially in languages that did not become dominant or languages whose ability was weaker than other languages. This lead to confusion in children so that the development of speech and language could be hampered.

\section{The effect of social environment on speech and language development of preschool children}

The result of this study showed that there was an effect of social environment on speech and language development of preschool children and it was statistically significant. A good social environment improved speech and language development of preschool children rather than poor social environments.

This study was in line with Jaenudin in Hasmy (2014), who stated that children social environment can lead to speech and language disorders in children. Unsupport- ing environments would cause speech and language disorders in children.

The social environment formed from the mature people which in this case were the educators and also the peers. Stimulation sourced from the social environment would be captured by the five senses and then the process of obtaining the language would occurred. Therefore, a good social environment would improve the development of speech and language of a child. Poor social environment decreased children speech and language development (Siregar, 2002).

\section{The effect of maternal education on speech and language development of preschool children}

The result of this study showed that there was an effect of maternal education on speech and language development among preschool children. High maternal education increased speech and language development among preschool children rather than mothers who were $<$ high school.

The result of this study is consistent with a study by Safriana (2017), which stated that there was a positive relationship between maternal education and the development of speech and language in children. Highly-educated mothers would seek information to improve their knowledge and skills in nurturing their children. Highlyeducated parents tend to be easy to received informations and applied in behavioral change.

A high level of maternal education has the ability to absorb information about the development of speech and language of the children. The informations could be obtained from social media, information from trusted persons, and health personnel. Therefore, the informations could be used to provide the stimulation for children to improve their speech and language development (Hastuti, 2010). 
Wijayanti et al./ The Effect of Parenting Style, Bilingual School, Social Environment,

Other studies have also shown a strong, consistent, and positive relationship between maternal education and the development of speech and language of children. Maternal education was a strong predictor of the development of speech and language in children. Children who were raised by families or mothers with low level of education would experience slow speech and language development than children who were raised by mothers with high level of education. High maternal education would make mothers to be more creative in teaching their children to read and stimulate their children so that the speech and language development of their children would be more quickly than low-educated mothers (Bingham et al, 2017).

\section{The effect of family income on speech and language development of preschool children}

The result of this study showed that there was an effect of family income on speech and language development among preschool children. High family income increased the speech and language development among preschool children.

The result of this study is consistent with a study by Dharmayanti et al. (2015), which stated that family with high income would maintain the health condition of their family and would make their family to live healthy including to provide good nutrition for children in order to improve children's speech and language development.

Income in the family also contributed to the child's development. Families with adequate income allowed the parents to provide a game tool as means of stimulating children's development. The family also tend to provide an environment that indirectly help the child to interact, therefore, the developmental stimulation occurred both physically and verbally (Freitas, 2013; Martini, 2012; Hastuti, 2009). Otherwise, families with low incomes cannot provide the basic needs of children who can stimulate their growth, especially their speech and language development (Soetjiningsih, 2012).

\section{The effect of children nutritional status on speech and language development of preschool children}

The result of this study showed that there was an effect of children nutritional status on speech and language development of preschool children. Good children nutritional status improved speech and language development among preschool children.

The result of this study is consistent with a study by Zulaikhah (2010), which stated that there was a relationship between children nutritional status and the development of speech and language in children. Nutritional status or the fulfillment of nutritional needs was one of the factors that influenced the development of children. If the children's nutritional needs were not fulfilled, then it would inhibit the development of the children.

According to Hidayat (2008), nutritional needs were very important in supporting the continuity of the growth and development process of the children, therefore, the fulfillment of good nutrition was necessary so that the children development could run normally.

\section{The effect of children's gender on speech and language development of preschool children}

The result of this study showed that there was an effect of children's gender on speech and language development among preschool children. Female children had higher speech and language development than male. The result of this study was in accordance with a study by Aprihantara et al. (2012), which stated that female children have better speech and language development than male, and one of the factors that affected 
Journal of Maternal and Child Health (2018), 3(3): 184-196

https://doi.org/10.26911/thejmch.2018.03.03.03

speech and language development was gender. In the first year of childhood, there was no difference in vocalizations between male and female. But from the age of two, female children showed faster development than male children.

This was in line with a study by Apriana (2009), which stated that in general, women tend to have high scores in terms of pronunciation. This could be due to a better association between the right and left brain in women. A study by Arifuddin (2010) showed that in female children, brain activation took place in both hemispheres and in larger areas. Women were more likely to remember a number of emotional images than men, and women were emotionally more effective than men in the development of speech and language naturally.

\section{The early childhood education program on speech and language development of preschool children}

Multilevel analysis result of ICC was 28.06\%. The indicator indicated that ECEP condition in each accreditation has contextual effect to speech and language development of preschool children by $28.06 \%$. ECEP with A accreditation were more likely to improve speech and language development of preschool children compared to ECEP with $\mathrm{B}$ accreditation and ECEP that have no accreditation. The result of this study was in line with a study by Aprihantara et al. (2012), which stated that there was a significant relationship between ECEP and speech and language development of preschool children, in other words, ECEP provided optimal developmental influence for preschool children, especially the development of speech and language.

ECEP provided social experience under the guidance of trained teachers who guide and help the children to develop their speech and language development.

\section{REFERENCES}

Apriana R (2009). Hubungan Pendidikan Anak Usia Dini (Paud dengan Perkembangan KognitiF Anak Usia Prasekolah di Kelurahan Tinjomoyo Kecamatan Banyumanik Semarang. Skripsi tidak diterbitkan. Semarang : Program Studi Ilmu Keperawatan Fakultas Kedokteran Universitas Diponegoro.

Aprihantara A, Astini PSN, Maryati LG (2012). Hubungan PAUD dengan Perkembangan Bahasa Anak Usia Prasekolah di Desa Sumerta Kaja Tahun 2012. Program Studi Ilmu Keperawatan Fakultas Kedokteran Universitas Udayana. Bali.

Arifuddin (2010). Neuropsikolinguistik. Jilidan Pertama. Jakarta: PT Rajagrafindo Persada.

Bingham GE, Jeon HY, Kwon KA (2017). Parenting Syle and home literacy opportunities: Associations with children's oral language skills. WILEY. Pp 1-18.

Candrasari A, Putri DEF, Warraihan, Parisa V (2017). Pengaruh Lingkungan terhadap Perkembangan Bahasa Anak. The $5^{\mathrm{TH}}$ Urecol Proceeding. UAD Yogyakarta. hlm. 972-978.

Candrasari JP (2014). Hubungan Pola Asuh Orang Tua dengan Perkembangan Bahasa Anak Prasekolah di RA Semai Benih Bangsa Al-Fikri Manca Bantul Yogyakarta. Skripsi. Sekolah Tinggi Ilmu Kesehatan Aisyiyah Yogyakarta.

Costa A, Galles NS (2015). How does the bilingual experience sculpt the brain?. Europe PMC Funders Group. 15(5): 336-345.

Dharmayanti I, Hapsari D, Azhar K (2015). Asthma among Children in Indonesia: Causes and Triggers. Jurnal Kesehatan Masyarakat Nasional. 9(4): 320326. 
Wijayanti et al./ The Effect of Parenting Style, Bilingual School, Social Environment,

Freitas TC, Gabbard C, Cocola PP, Montebelo, Santos (2013).Family socioeconomic Status and the Provision of Affordances in the Home. Epub. 17(4): 319-27.

Gunawan G, Destiana, Rusmil K (2011). Gambaran Perkembangan Bicara dan Bahasa Anak Usia 0-3 Tahun. Sari Pediatri. vol. 13, no. 1, hlm. 21-25.

Guyer A, Jarcho J, Edgar P, Degnan K, Pine D, Nathan F, Nelson E (2016). Temperament and Parenting Styles in Early Childhood Differentially Influence Neural Response to Peer Evaluation in Adolescence. J Abnorm Child Psychol. 43(5): 863-874.

Hartanto F, Selina H, Zuhriah, Fitra S (2011). Pengaruh Perkembangan Bahasa Terhadap Perkembangan Kognitif Anak Usia 1-3 Tahun. Sari Pediatri. 12(6): 386-390.

Hasmy R (2014). Perbedaan Perkembangan Bahasa pada Anak Usia Toddler di RW 17 Kelurahan Pisangan Kecamatan Ciputat Timur dengan Anak Usia Toddler di PSSA Balita Tunas Bangsa Cipayung. Skripsi. Universitas Islam Negeri Syarif Hidayatullah Jakarta.

Hastuti (2010). Nilai Anak, Stimulasi Psikososial, dan Perkembangan Kognitif Anak Usia 2-3 tahun pada Keluarga Rawan Pangan di Kabupaten Banjarnegara,Jawa Tengah. Institut Pertanian Bogor. Jurnal Ilmu Keluarga dan Konsumen. 3(1): 21-34.

Hidayat AA (2008). Pengantar Ilmu Kesehatan Anak untuk Pendidikan Kebidanan. Jakarta: Salemba Medika.

Israfil (2015). Hubungan Pola Asuh Orang Tua dengan Perkembangan Anak Usia Prasekolah. Seminar Psikologi \& Kemanusiaan. Program Studi Magister Sains Psikologi. Universitas Muhammadiyah Malang.
Madyawati L (2016). Strategi Pengembangan Bahasa Pada Anak Edisi Pertama. Jakarta: Prenadamedia Group.

Marmi, Raharjo K (2012). Asuhan Neonatus, Bayi, Balita dan Anak Prasekolah. Yogyakarta: Pustaka Pelajar.

Meyer B (2012). Ad hoc interpreting for partially language-proficient patients. John Benjamins Publishing Company. 4: 100-113.

Nayeb L, Wallby T, Westerlund M, Salameh EK, Sarkadi A (2014). Child Healthcare Nurses Believe That Bilingual Children Show Slower Language Development, Simplify Screening Procedures And Delay Referrals. Foundation Acta Paediatrica. hlm. 198-205.

Putri RA, Murti B, Indarto D (2016). Effect of Nurturing at Child Care Center on Gross and Fine Motoric, Language and Social Development in Children Aged Under Five Years in Ungaran Barat Subdistrict, Ungaran. Journal of Maternal and Child Health. 2(1): 1-9.

Restiyani, Lestari S, Halida (2013). Hubungan Pola Asuh dengan Perkembangan Bicara Anak Usia 4-5 Tahun TK ALFalah Mempawah. Artikel Penelitian. PG-PAUD, FKIP Universitas Tanjungpura, Pontianak.

Safriana L, Salimo H, Dewi YLR (2017). Biopsychosocial Factors, Life Course Perspective, and Their Influences on Language Development in Children. Journal of Maternal and Child Health, 2(3): 245-256.

Sari S, Memy Y, Ghanie A (2015). Angka Kejadian Delayed Speech Disertai Gangguan Pendengaran pada Anak yang Menjalani Pemeriksaan Pendengaran di Bagian Neurootologi IKTHTKL RSUP Dr.Moh. Hoesin. Jurnal Kedokteran Dan Kesehatan. 2(1): 121127. 
Journal of Maternal and Child Health (2018), 3(3): 184-196

https://doi.org/10.26911/thejmch.2018.03.03.03

Sari, Budisetyani W (2016). Konsep Diri Pada Anak Dengan Orangtua Yang Bercerai. Jurnal Psikologi Udayana. 3(2): 283-291.

Soetjiningsih (2012). Tumbuh Kembang Anak. Jakarta : EGC.

Sumaryanti L (2017). Peran Lingkungan terhadap Perkembangan Bahasa Anak. MUADDIB. 07(01): 72-89.

Sutisna I (2017). Pola Asuh Orang Tua dan Perilaku Agresi Anak. hlm 105-114. Prosiding Seminar Nasional dan Lokakarya PLS FIP UNG Reaktualisasi Pendidikan Luar Sekolah sebagai Pem- berdaya Masyarakat. dalam Hamid I, Yakob N dan Moh Z (edt.) . UNG Press Gorontalo.

Siregar MA (2002). Pengaruh Stimuli Terhadap Pemerolehan Bahasa Anak Prasekolah. Thesis. Medan: Program Studi Linguistik Universitas Sumatera Utara.

Zulaikhah S (2010). Hubungan Status Gizi dengan Perkembangan Anak Usia 2 sampai 3 Tahun di Wilayah Kerja Puskesmas Gambiran Kota Surakarta. Karya Tulis Ilmiah. Universitas Sebelas Maret Surakarta. 